\title{
Response of Corn-Soybean Intercropping to Fertilizer Packages in Dry Land with Dry Climate
}

\author{
DOI: $10.18196 /$ pt.v9i2.4378
}

\author{
Afandi Kristiono, Siti Muzaiyanah* \\ Indonesian Legumes and Tuber Crops Research Institute, \\ Jl. Raya Kendalpayak KM 8. Po Box 66 Malang, East Java, 65101, Indonesia \\ *Corresponding author, email: muzayanahid@yahoo.com
}

\begin{abstract}
Intercropping soybean with corn on dry land with dry climate (DLDC) is an alternative program to expand the soybean cultivation harvested area. This study evaluated the effectiveness of fertilization performance in the intercropping of soybean-corn in DLDC. The experiment in this study was arranged in a randomized block design, consisting of seven fertilizer package treatments with four replications. The spacing between corn (Pertiwi 3) and soybean (Dena 1) was (50 cm x $200 \mathrm{~cm}$ ) $40 \mathrm{~cm}$ (2 plants/clump) and between soybeans (Dena 1) was $40 \mathrm{~cm} \times 15 \mathrm{~cm}$ (2-3 plants/clumps). The observations consisted of soil analysis (pH, organic matter, total N (Kjeldahl), available P, Ca-dd, Mg-dd, K-dd, and Na-dd), soybean leaf chlorophyll index (45 and 60 days after planting/ dap), plant height at (45 daps and harvest), number and weight of root nodules (45 daps); Corn: chlorophyll index (56 daps), plant height (harvest), analysis of corn and soybean plant tissue (60 daps), yield, and yield components of dry seeds of soybean and corn per hectare. The results showed that effective fertilization for the intercropped crops was $53 \mathrm{~kg} \mathrm{~N}+1,500 \mathrm{~kg}$ of manure per hectare in corn plant and $7 \mathrm{~kg} \mathrm{~N}+22 \mathrm{~kg} P 205+18 \mathrm{~kg}$ K20 + 1,500 kg/ha manure + Rhizobium lletrisoy/Agrisoy in soybean crops.

Keywords: Corn, Fertilizing, Intercropping, Soybean
\end{abstract}

\section{ABSTRAK}

Budidaya tumpangsari kedelai dengan jagung pada lahan kering iklim kering (LKIK) merupakan salah satu alternatif untuk memperluas areal tanam kedelai. Penelitian ini bertujuan untuk mengevaluasi kinerja pemupukan yang efektif untuk pertanaman tumpangsari kedelai-jagung pada LKIK.Penelitian menggunakan rancangan acak kelompok dengan tujuh paket perlakuan pemupukan diulang empat kali. Jarak tanam tumpangsari jagung (Pertiwi 3) dengan kedelai (Dena 1)adalah (50 cm x 200 cm) x 40 cm (2 tanaman/rumpun) + kedelai (Dena 1) berjarak tanam 40 cm x 15 cm (2-3 tanaman/rumpun). Pengamatan terdiri atas: (1) analisis tanah meliputi: pH, bahan organik, N-total (Kjeldahl), P-tersedia, Ca-dd, Mg-dd, K-dd, dan Na-dd; (2) Kedelai: indeks klorofil daun (45 hst dan 60 hst), tinggi tanaman (45 hst dan panen), jumlah dan berat bintil akar (45 hst); (3) Jagung: indeks klorofil (56 hst), tinggi tanaman (panen); (4) analisa jaringan tanaman jagung dan kedelai (60 hst), (5) komponen hasil dan hasil biji kering kedelai dan jagung per hektar.Hasil penelitian menunjukkan bahwa pemupukan efektif pada pertanaman tumpangsari adalah: $53 \mathrm{~kg} \mathrm{~N}+1.500 \mathrm{~kg}$ pupuk kandang per hapada tanaman jagung dan: $7 \mathrm{~kg} \mathrm{~N}+22 \mathrm{~kg}$ P205 + 18 kg K20 + 1.500 kg/ha pupuk kandang + Rhizobium Iletrisoy/Agrisoy pada tanaman kedelai.

Kata Kunci: jagung, kedelai, pemupukan, tumpangsari

\section{INTRODUCTION}

The production of soybean in Indonesia has not successfully fulfilled the national needs. The need for soybeans for both food and industry continues to increase from year to year. The average national demand for soybeans is \pm 2.2 million tons each year (Directorate General of Food Crops, 2015), while domestic production only reaches 963,099 tons, only $43.8 \%$ of the total needs (BPS 2016). Consequently, a production deficit of $56.2 \%$ must be met from imports. Therefore, efforts are needed to increase soybean production to reduce this dependence.
The main problem in increasing soybean production is that the soybean planting area is not large enough with low productivity. Sumarno and Adie (2010) stated that land allocation specifically intended to support the soybean production system is still unavailable. Hence, the planting area cannot be thoroughly determined. Besides, soybean farming is classified as high risk with low productivity and income, discouraging farmers from cultivating soybeans. However, the opportunity to increase soybean production is still quite wide by utilizing cultivation technology, suitable climate, and sub- 
optimal land use.

Using dry land with a dry climate (DLDC) is an alternative to expanding the soybean planting area. DLDC in Indonesia is around 13.3 million hectares, 7.8 million hectares of which can be potentially used for agriculture (Mulyani and Sarwani, 2013). The DLDC area suitable for developing food crops is around 2.23 million ha spread over 886,000 ha in Java (especially East Java), 219,000 ha in Sulawesi, and 1,122 ha in Nusa Tenggara (Sukarman et al. 2012). NTT has the highest proportion of dry land with a dry climate, around 3.3 million ha $(71.7 \%$ of the total area of NTT) (Mulyani 2013).

Dry land with a dry climate has less than 2,000 $\mathrm{mm} /$ year (Mulyani and Sarwani 2013). This land is generally distributed in areas of type D and $E$ climates according to Oldeman's classification, so it has less than three to four wet months (rainfall> $200 \mathrm{~mm} / \mathrm{month}$ ) and has four to more than six dry months (rainfall $<100 \mathrm{~mm} /$ month) in a year. This condition causes water availability to be the main limiting factor in the use of DLDC for agriculture. Agricultural development at DLDC requires an arrangement of planting and pattern and a supply of surface water during the dry season (Mulyani, 2013; Kartiwa and Dariah, 2012).

Soils commonly found in DLDC in Indonesia are Vertisols, Alfisols, Mollisols, and Entisols, which generally react $(\mathrm{pH})$ neutral to slightly alkaline because they are relatively rich in cations/bases (base saturation> 50\%) (Mulyani and Sarwani, 2013). The content of organic matter and $\mathrm{N}$ in the soil is generally low to very low (Rosariastuti et al., 2012), so it requires additional organic matter and $\mathrm{N}$ nutrient source fertilizers to improve soil fertility.

In dry land areas with dry climates, corn is a food crop commodity predominantly cultivated by farmers for staple food and sources of income other than peanuts and mung beans. Soybean could be developed in DLDC because it can in- crease the Harvest Index (HI), break the cycle of pests and disease, and increase farming efficiency. The efficiency includes managing the soil, which does not need tillage, residual fertilizers, relatively light weed growth, and soybean residues as green manure (Winardi, 2014). Also, soybeans have a harvest age of 73-90 days, which is relatively the same as corn and peanuts and requires relatively less water than corn. However, soybean cultivation by monoculture in the DLDC area will certainly be difficult for farmers because it will reduce the area and production of corn. In this regard, soybean cultivation must be intercropped with corn through optimal and efficient crop management and fertilization by observing/harmonizing existing agricultural resources. Putri (2011) reported that the income from corn-peanut intercropping reached Rp. 8,449. 479.00 / ha/planting season, while that from corn monoculture farming only reached Rp. 5,893,727.00 / ha / planting season. In tidal fields, intercropping soybeans with corn with a composition of 3: 1 for two planting periods increased the yield of shelled corn by $140 \%$ and soybean yield by $16 \%$ compared to monocultures (Aminah et al., 2014). Intercropping farming is more efficient to develop than corn monoculture. On the other hand, intercropping can also increase the dry seed weight per plot of hybrid corn compared to non-hybrid corn. The weight of dry shelled seeds produced by hybrid corn with an intercropping pattern can reach $2.60-3.30 \mathrm{~kg}$ / m2, equivalent to 5.77-7.34 tons/ha (Yuwariah et al., 2017).

This study aims to evaluate the performance of fertilization in the intercropping of soybeans and corn on dry land with a dry climate, following environmental conditions to support the development of bio-industrial agriculture.

\section{MATERIALS AND METHODS}

The study was conducted on dry land (type D 
Table 1. Effects of fertilization packages on corn-soybean intercropping in a dry land with dry climate in Madiun in MH 2015/2016

\begin{tabular}{cccccccccc}
\hline \multirow{2}{*}{$\begin{array}{c}\text { Fertilization } \\
\text { packages }\end{array}$} & \multicolumn{4}{c}{ Fertilizer for corn $\left.(\mathrm{kg} / \mathrm{ha})^{*}\right)$} & \multicolumn{5}{c}{ Fertilizer for soybean $\left.(\mathrm{kg} / \mathrm{ha})^{*}\right)$} \\
\cline { 2 - 10 } & $\mathrm{N}$ & P205 & K20 & Manure & N & P205 & K20 & Manure & Rhizobium $\left.^{* *}\right)$ \\
\hline A & 0 & 0 & 0 & 0 & 0 & 0 & 0 & 0 & - \\
B & 67,5 & 36 & 30 & 0 & 22,5 & 36 & 30 & 0 & - \\
C & 67,5 & 0 & 0 & 2.500 & 22,5 & 0 & 0 & 2.500 & - \\
D & 67,5 & 36 & 30 & 2.500 & 22,5 & 36 & 30 & 2.500 & - \\
E & 90 & 44 & 30 & 0 & 11,3 & 36 & 30 & 0 & + \\
F & 90 & 0 & 0 & 2.500 & 11,3 & 36 & 30 & 2.500 & + \\
G & 90 & 44 & 30 & 2.500 & 11,3 & 44 & 30 & 2.500 & + \\
\hline
\end{tabular}

Remarks: *: Fertilizer dosage is equivalent to that in the full monoculture population (the population in intercropping consisted of $59 \%$ corn and $61 \%$ soybean).

**: Rhizobium lletrisoy/Agrisoy (seed treatment)

Table 2. Initial soil analysis, Madiun, 2016

\begin{tabular}{cccc}
\hline Variables & Method & \multicolumn{2}{c}{ Analysis results } \\
\cline { 3 - 4 } pH-H20 & $1: 2.5$ & Value & Status \\
Organic C (\%) & Walkley \& Black & 7.5 & Alkaline \\
Total N (\%) & Kjeldahl & 1.52 & Very low \\
Available P $(\mathrm{ppm})$ & Bray-1 & 0.12 & Low \\
K-dd (me/100 g) & NH4-OAc pH 7,0 & 69.0 & Very high high \\
Mg-dd (me/100 g) & NH4-OAc pH 7,0 & 1.15 & High \\
Na-dd (me/100 g) & NH4-OAc pH 7,0 & 4.95 & Very high \\
CEC (me/100 g) & & 1.41 & 69.35 \\
\hline
\end{tabular}

climate according to Oldeman's classification) in Pajaran Village, Saradan District, Madiun Regency, (7033'18.076 “S, 111046’ 51.675” E; 126 m asl) in $\mathrm{MH}$ 2015/2016. The research area belongs to Perhutani, originally a teak plantation area, which farmers then opened and used for planting crops (corn and peanuts) for more than five years. Soil characteristics in the study location are presented in Table 2. The experiment was arranged in a randomized block design, consisting of seven fertilization treatments with four replications (Table 1).

Land preparation was carried out through perfect tillage. The planting of corn and soybeans was carried out simultaneously. The corn-soybean intercropping pattern used was corn (Pertiwi 3) with double rows spacing of $(50 \mathrm{~cm} \times 200 \mathrm{~cm}) \times$ $40 \mathrm{~cm}$ ( 2 plants / clump) + soybeans (Dena 1$)$ with spacing of $40 \mathrm{~cm} \times 15 \mathrm{~cm}$ (2-3 plants / clump).
Each treatment was planted in an experimental plot measuring $7.5 \mathrm{~m} \times 3.5 \mathrm{~m}$. The application of fertilizers to the corn plants consisted of manure applied at planting by spreading it in rows of plants, $30 \% \mathrm{~N}+100 \% \mathrm{P} 2 \mathrm{O} 5+50 \% \mathrm{~K} 2 \mathrm{O}$ applied seven days afterward, and 70\% N + 50\% K2O applied 25 days afterward. Inorganic fertilizers were applied continuously beside the clumps of plants about $5-7 \mathrm{~cm}$ away. For soybean, the fertilizer application included Rhizobium Iletrisoy / Agrisoy applied as a seed treatment (before planting), manure applied by sowing (covering the soil hole) at planting time, and $100 \%$ inorganic fertilizer applied in grooves about $5-7 \mathrm{~cm}$ next to planting rows at 7-10 days after planting. Manure and inorganic fertilizers in intercropping were adjusted based on clump population per hectare of monoculture crops (corn population was 33,000 clumps, and soybean popu- 
lation was 166,000 clumps per ha). The control of availability, thereby requiring the intake of organic weeds, pests, and diseases was performed according matter and $\mathrm{N}$ nutrients to obtain maximum plant to conditions in the field.

The observations consisted of the initial analysis of composite soil samples with a depth of $0-20 \mathrm{~cm}$ ( $\mathrm{pH}$, organic matter, total $\mathrm{N}$ (Kjeldahl), available $\mathrm{P}$, K-dd, Mg-dd, Na-dd, and CEC), analysis of plant tissues (soybeans and corn) taken compositely in replications at 60 days after planting (DAP), the number and weight of soybean root nodules at 45 DAP, the chlorophyll content of soybean (at 45 DAP and 60 DAP) and corn leaves (at 56 DAP) using Chlorophyll meter SPAD-502, the height of soybean (at 45 DAP and harvest) and corn at harvest, yield components and yields of soybean and corn dry seeds per hectare, and biomass weight of corn and soybean per hectare.

\section{RESULTS AND DISCUSSION}

\section{Soil Characteristics}

The soil in the research location is classified as Vertisol (Grumusol) soil, which reacts alkaline with low organic matter content and nutrient $\mathrm{N}$ production. However, this soil contains high available $\mathrm{P}, \mathrm{K}$-dd, and Mg-dd nutrients. The high value of the Cation Exchange Capacity (CEC) results in the ability of the soil to absorb alkaline cations, which results in a high soil pH (Sudaryono, 2009) (Table 2). The annual climatic conditions, including rainfall, air temperature, and humidity during the experiment, are presented in Table 3.

\section{Growth and Yield of Soybean}

\section{Plant growth}

The analysis of variance showed that different fertilization packages had no significant effect on the height growth of soybean plants. However, the plant height in the fertilization treatments (B - $G$ packages) tended to be higher than in control (package A) 45 days after planting and harvest. At 45 days after planting and harvest, plant height ranged between $40.26-47.44 \mathrm{~cm}$ and $59.90-68.13$ $\mathrm{cm}$, respectively. Rhizobium inoculants to the $\mathrm{E}, \mathrm{F}$, and $G$ packages did not significantly affect plant
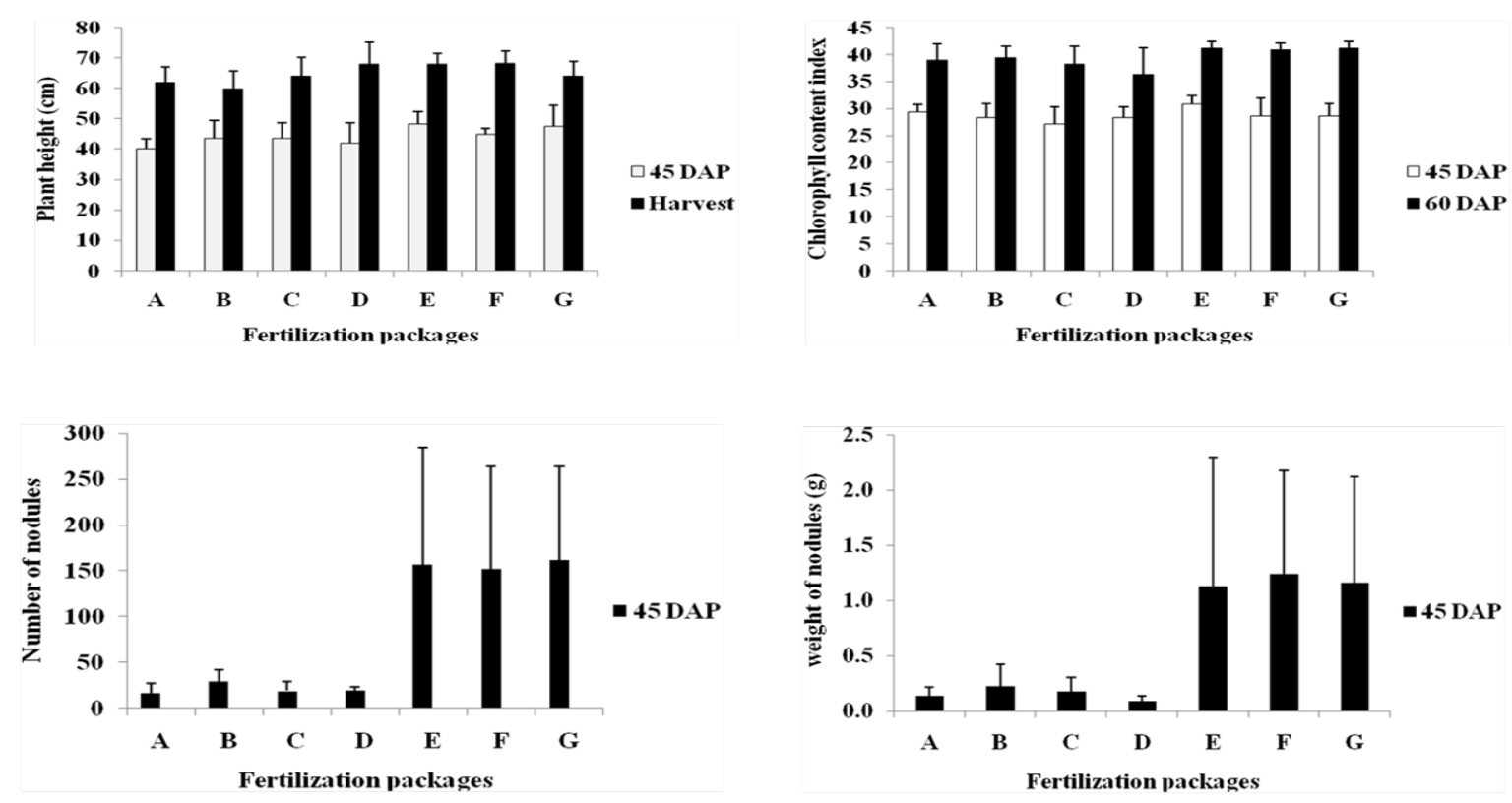

Figure 1. Effects of fertilization packages on the plant height, chlorophyll content index, number of nodules, and weight of nodules. 
Table 3. Average rainfall, temperature, and humidity, Madiun, 2016

\begin{tabular}{cccc}
\hline Variables & \multicolumn{3}{c}{ Average } \\
\cline { 2 - 4 } & Rainfall $(\mathrm{mm})$ & Temperature $\left({ }^{\circ} \mathrm{C}\right)$ & Humidity $(\%)$ \\
\hline January & 19.13 & 24.00 & 79 \\
February & 24.46 & 23.86 & 84 \\
March & 23.30 & 23.81 & 82 \\
April & 17.89 & 24.30 & 80 \\
May & 13.79 & 23.98 & 79 \\
June & 21.18 & 23.97 & 80 \\
July & 7.56 & 24.06 & 80 \\
August & 10.33 & 23.73 & 75 \\
September & 16.73 & 23.90 & 74 \\
October & 22.30 & 23.90 & 79 \\
November & 23.63 & 23.80 & 68 \\
December & 21.53 & 23.80 & 77 \\
\hline
\end{tabular}

height. The plant height of the 'Dena 1' variety is $60 \mathrm{~cm}$ (59 $\mathrm{cm}$ based on the variety description) under normal conditions. In this study, the soybean plant height was considered normal without etiolation despite corn plants' shading.

The different fertilization packages significantly affected the leaf chlorophyll content, the number of nodules, and the weight of nodules at all observation times (Figure 1). The chlorophyll content index (CCI) at 60 days after planting was higher than that at 45, which was 36.28-41.15 and 27.22 -29.30, respectively (Figure 1). This result showed an increase in chlorophyll content in the leaves, increasing the plant's photosynthetic ability. The chlorophyll content in the E, F, and G fertilization packages was higher $(5 \%)$ than in other fertilization packages. This possibility is related to the administration of Rhizobium (Iletrisoy / Agrisoy) inoculant in the fertilization treatment. Rhizobium can trigger the growth of root nodules and the nitrogenase enzyme content contained in root nodules. It is alleged to increase nitrogen fixation from the air, thereby increasing nitrogen content, which will increase plant biomass and production (Purwaningsih, 2015).

The addition of Rhizobium inoculant in seed treatment effectively increased the number and weight of nodules 45 days after planting. In the fertilization package with Rhizobium inoculants (E, F, and G), the number of nodules ranged from 152.3-161.5 nodules per plant. Without Rhizobium treatment, the number of nodules was only 8.3-11.3 nodules per plant. The weight of nodules increased significantly (>100\%) in the treatment with rhizobium inoculants. Visual observation showed that the size and the number of nodules in the rhizobium inoculant treatment were more significant. The split nodules were pink, indicating Rhizobium in the nodules was active in nitrogen fixation. The nodules were positively correlated with CCI at 60 days after planting $\left(\mathrm{r}=0.85^{*}, \mathrm{n}=\right.$ $5)$. Thus, the number of nodules determined the $\mathrm{CCI}$ at 60 days after planting.

\section{The content of N, P, and K nutrients in the soybean} leaves

The youngest leaves that had fully opened 60 days after planting (third or fourth leaf) were used to analyze the nutrient content in soybean leaves (Table 3). The content of N, P, and $\mathrm{K}$ in the leaves was $2.95-3.28 \%, 0.15-0.17 \%$, and 0.72 $0.83 \%$, consecutively. The application of fertilizers 
Table 4 The content of N, P, and $\mathrm{K}$ in the youngest leaves of soybean plants intercropped with corn plants taken compositely in replication 60 days after planting, Madiun, 2016

\begin{tabular}{|c|c|c|c|c|c|c|c|c|c|c|c|c|}
\hline \multirow{2}{*}{$\begin{array}{c}\text { Fertilization } \\
\text { packages }\end{array}$} & \multicolumn{4}{|c|}{ Fertilizer for corn $\left.(\mathrm{kg} / \mathrm{ha})^{*}\right)$} & \multicolumn{5}{|c|}{ Fertilizer for soybean $\left.(\mathrm{kg} / \mathrm{ha})^{*}\right)$} & \multicolumn{3}{|c|}{ Nutrient content in soybean (\%) } \\
\hline & $\mathrm{N}$ & P205 & K20 & Manure & $\mathrm{N}$ & P205 & K20 & Manure & Rhizobium**) & $\mathrm{N}$ & $\mathbf{P}$ & K \\
\hline A & 0 & 0 & 0 & 0 & 0 & 0 & 0 & 0 & - & 2.95 & 0.15 & 0.72 \\
\hline B & 67,5 & 36 & 30 & 0 & 22,5 & 36 & 30 & 0 & - & 3.44 & 0.17 & 0.74 \\
\hline C & 67,5 & 0 & 0 & 2.500 & 22,5 & 0 & 0 & 2.500 & - & 3.25 & 0.17 & 0.80 \\
\hline D & 67,5 & 36 & 30 & 2.500 & 22,5 & 36 & 30 & 2.500 & - & 3.02 & 0.16 & 0.71 \\
\hline $\mathrm{E}$ & 90 & 44 & 30 & 0 & 11,3 & 36 & 30 & 0 & + & 3.27 & 0.16 & 0.78 \\
\hline $\mathrm{F}$ & 90 & 0 & 0 & 2.500 & 11,3 & 36 & 30 & 2.500 & + & 3.72 & 0.15 & 0.63 \\
\hline G & 90 & 44 & 30 & 2.500 & 11,3 & 44 & 30 & 2.500 & + & 3.28 & 0.17 & 0.83 \\
\hline
\end{tabular}

Remarks: *: Fertilizer dosage is equivalent to that in the full monoculture population (the population in intercropping consisted of $59 \%$ corn and $61 \%$ soybean).

**: Rhizobium lletrisoy/Agrisoy (seed treatment)

Table 5 Effects of fertilization packages on the yield and yield component of soybean plants intercropped with corn plants, Madiun, MH 2015/2016

\begin{tabular}{|c|c|c|c|c|c|}
\hline \multirow{2}{*}{ Fertilization packages } & \multicolumn{3}{|c|}{ Number /plant } & \multirow{2}{*}{$\begin{array}{l}\text { Seed yield } \\
(t / h)\end{array}$} & \multirow{2}{*}{$\begin{array}{c}\text { Biomass weight } \\
(\mathrm{t} / \mathrm{h})\end{array}$} \\
\hline & Branches & Filled pods & Empty pods & & \\
\hline A & $3.6 \mathrm{a}$ & $37.33 \mathrm{~b}$ & $92.8 \mathrm{a}$ & $0.80 c$ & $3.11 \mathrm{a}$ \\
\hline B & $4.0 \mathrm{a}$ & $43.63 \mathrm{ab}$ & $12.13 \mathrm{a}$ & $1.04 b$ & $4.70 \mathrm{a}$ \\
\hline C & $3.9 \mathrm{a}$ & $45.75 a b$ & $14.18 \mathrm{a}$ & $1.22 \mathrm{ab}$ & $4.67 \mathrm{a}$ \\
\hline D & $4.3 \mathrm{a}$ & $48.05 \mathrm{a}$ & $14.58 \mathrm{a}$ & $1.09 \mathrm{~b}$ & $5.19 \mathrm{a}$ \\
\hline $\mathrm{E}$ & $4.0 \mathrm{a}$ & $48.15 \mathrm{a}$ & $9.93 \mathrm{a}$ & $1.27 \mathrm{ab}$ & $3.91 \mathrm{a}$ \\
\hline $\mathrm{F}$ & $4.2 \mathrm{a}$ & $53.03 \mathrm{a}$ & $11.80 \mathrm{a}$ & $1.40 \mathrm{a}$ & $4.43 \mathrm{a}$ \\
\hline G & $4.2 \mathrm{a}$ & $52.80 \mathrm{a}$ & $9.95 \mathrm{a}$ & $1.36 \mathrm{a}$ & $4.26 \mathrm{a}$ \\
\hline
\end{tabular}

Remarks: Means followed by the same letters within the same column are not significantly different based on the LSD test at 5\%.

using various fertilization packages, in general, weight of biomass per hectare. Fertilization treatdid not have much effect on the $\mathrm{P}$ and $\mathrm{K}$ nutrient ments (package B-package $\mathrm{G}$ ) were able to increase content but increased the $\mathrm{N}$ content. It happened the number of filled pods by $17-42 \%$ compared to because the soil's available P and K-dd content were control (package A) (Table 4). The increase in filled classified as high, so the addition of fertilizers did pods due to the treatment of various fertilizers led not significantly affect the $\mathrm{P}$ and $\mathrm{K}$ in leaves. On to the rise in the yield of dry seeds. In the control the other hand, the total $\mathrm{N}$ content in the soil was treatment, soybean yield in the intercropping sysclassified as low so that the plant was sufficiently tem was $0.80 \mathrm{t} / \mathrm{ha}$. In contrast, in the fertilizer responsive to fertilizer application, as indicated by package treatments, soybean yield increased to an increase in the $\mathrm{N}$ content in the leaves.

\section{Yield and yield component}

Fertilization treatment had a significant effect on the number of filled pods and seed yield but had no significant impact on the number of branches/plants, empty pods/plants, and the $1.04-1.40 \mathrm{t} / \mathrm{ha}$, varied depending on the type and dose of fertilizer given. The highest yield of soybean seeds was obtained in the treatment of $\mathrm{F}$ fertilization packages.

The yield of soybean stover (dry), consisting of pod bark, branches, and soybean stems, increased with fertilization in all fertilizer packages. Without 
Planta Tropika: Jurnal Agrosains (Journal of Agro Science) Vol. 9 No. 2 / August 2021

Table 6. Plant population, plant height, and chlorophyll content of corn plants intercropped with soybean plants as affected by various fertilization packages, Madiun, 2016

\begin{tabular}{cccccccccc}
\hline \multirow{2}{*}{$\begin{array}{c}\text { Fertilization } \\
\text { packages }\end{array}$} & \multicolumn{3}{c}{ Fertilizer for corn $\left.(\mathrm{kg} / \mathrm{ha})^{*}\right)$} & \multicolumn{5}{c}{ Fertilizer for soybean $\left.(\mathrm{kg} / \mathrm{ha})^{*}\right)$} \\
\cline { 2 - 10 } & $\mathrm{N}$ & $\mathrm{P} 205$ & $\mathrm{~K} 20$ & Manure & $\mathrm{N}$ & P205 & K20 & Manure & Rhizobium $\left.^{* *}\right)$ \\
\hline A & 0 & 0 & 0 & 0 & 0 & 0 & 0 & 0 & - \\
B & 67,5 & 36 & 30 & 0 & 22,5 & 36 & 30 & 0 & - \\
C & 67,5 & 0 & 0 & 2.500 & 22,5 & 0 & 0 & 2.500 & - \\
D & 67,5 & 36 & 30 & 2.500 & 22,5 & 36 & 30 & 2.500 & - \\
E & 90 & 44 & 30 & 0 & 11,3 & 36 & 30 & 0 & + \\
F & 90 & 0 & 0 & 2.500 & 11,3 & 36 & 30 & 2.500 & + \\
G & 90 & 44 & 30 & 2.500 & 11,3 & 44 & 30 & 2.500 & + \\
\hline
\end{tabular}

Remarks: *: Full population of plants (100\%): 108 plants/plot

**: Means followed by the same letters within the same column are not significantly different based on the LSD test at $5 \%$

Table 7. The content of N, P, and $\mathrm{K}$ in the leaves of corn plants intercropped with soybean plants taken compositely in replication 60 days after planting, Madiun, 2016

\begin{tabular}{|c|c|c|c|c|c|c|c|c|c|c|c|c|}
\hline \multirow{2}{*}{$\begin{array}{c}\text { Fertilization } \\
\text { packages }\end{array}$} & \multicolumn{4}{|c|}{ Fertilizer for corn $\left.(\mathrm{kg} / \mathrm{ha})^{*}\right)$} & \multicolumn{5}{|c|}{ Fertilizer for soybean $\left.(\mathrm{kg} / \mathrm{ha})^{*}\right)$} & \multicolumn{3}{|c|}{ Nutrient content in soybean $(\%)$} \\
\hline & $\mathrm{N}$ & P205 & K2O & Manure & $\mathrm{N}$ & P205 & K20 & Manure & Rhizobium**) & $\mathrm{N}$ & $\mathbf{P}$ & K \\
\hline A & 0 & 0 & 0 & 0 & 0 & 0 & 0 & 0 & - & 1.25 & 0.10 & 0.87 \\
\hline B & 67,5 & 36 & 30 & 0 & 22,5 & 36 & 30 & 0 & - & 1.55 & 0.12 & 0.78 \\
\hline C & 67,5 & 0 & 0 & 2.500 & 22,5 & 0 & 0 & 2.500 & - & 1.57 & 0.07 & 0.66 \\
\hline D & 67,5 & 36 & 30 & 2.500 & 22,5 & 36 & 30 & 2.500 & - & 1.53 & 0.14 & 0.82 \\
\hline$E$ & 90 & 44 & 30 & 0 & 11,3 & 36 & 30 & 0 & + & 1.71 & 0.13 & 0.83 \\
\hline $\mathrm{F}$ & 90 & 0 & 0 & 2.500 & 11,3 & 36 & 30 & 2.500 & + & 1.84 & 0.13 & 0.68 \\
\hline G & 90 & 44 & 30 & 2.500 & 11,3 & 44 & 30 & 2.500 & + & 1.77 & 0.14 & 0.70 \\
\hline
\end{tabular}

Remarks: *: Fertilizer dosage is equivalent to that in the full monoculture population (the population in intercropping consisted of $59 \%$ corn and $61 \%$ soybean).

**: Rhizobium Iletrisoy/Agrisoy (seed treatment)

fertilization, the yield of soybean stover (dry) was $3.11 \mathrm{t} / \mathrm{ha}$, while the yield of those fertilized varied between 3.91-5.19 $\mathrm{t} / \mathrm{ha}$. In line with the seed yield, the highest stover yield was observed in the F fertilization package.

\section{Growth and Yield of Corn Plants}

\section{Pant growth}

The analysis of variance showed that the fertilization package had a significant effect on the number of plant populations because fertilizers affect seed viability and vigor (Widuri, 2006). Thus, the cropping population that was applied fertilizer was higher than those that were not fertilized (control). Fertilization also significantly affected the plant height (at harvest) and the chlorophyll con- tent index (at 56 days after planting). In this study, corn plants were attacked by downy mildew, so replanting had to be done. The second corn plantation, despite the seed treatment using fungus, was also struck by downy mildew. Consequently, the harvested plant population was deficient, ranging from $18.80-41.02 \%$ (Table 5). All fertilization package treatments significantly increased the population of harvested plants, meaning that the treatments could reduce the incidence of downy mildew compared to the control.

The height growth of the corn plant varied as affected by the fertilization packages. In general, the treatment of all fertilization packages increased the height of the corn plants at harvest. The plants' 
Table 8. The content of N, P, and K in the leaves of corn plants intercropped with soybean plants taken compositely in replication 60 days after planting, Madiun, 2016

\begin{tabular}{|c|c|c|c|c|c|c|c|c|c|c|c|}
\hline \multirow{2}{*}{$\begin{array}{c}\text { Fertilization } \\
\text { packages }\end{array}$} & \multicolumn{4}{|c|}{ Fertilizer for corn $\left.(\mathrm{kg} / \mathrm{ha})^{*}\right)$} & \multicolumn{5}{|c|}{ Fertilizer for soybean $\left.(\mathrm{kg} / \mathrm{ha})^{\star}\right)$} & \multicolumn{2}{|c|}{ Yield/dry weight (t/ha) } \\
\hline & $\mathrm{N}$ & P205 & $\mathrm{K} 20$ & Manure & $\mathrm{N}$ & P205 & K20 & Manure & Rhizobium**) & Seed & Bio- mass*** \\
\hline A & 0 & 0 & 0 & 0 & 0 & 0 & 0 & 0 & - & $0.37 c$ & $0.88 d$ \\
\hline B & 67,5 & 36 & 30 & 0 & 22,5 & 36 & 30 & 0 & - & $0.73 b c$ & $2.00 \mathrm{bc}$ \\
\hline C & 67,5 & 0 & 0 & 2.500 & 22,5 & 0 & 0 & 2.500 & - & $0.47 c$ & $1.48 \mathrm{~cd}$ \\
\hline D & 67,5 & 36 & 30 & 2.500 & 22,5 & 36 & 30 & 2.500 & - & $0.73 b c$ & $2.00 \mathrm{abc}$ \\
\hline $\mathrm{E}$ & 90 & 44 & 30 & 0 & 11,3 & 36 & 30 & 0 & + & $1.38 \mathrm{a}$ & $2.50 \mathrm{a}$ \\
\hline $\mathrm{F}$ & 90 & 0 & 0 & 2.500 & 11,3 & 36 & 30 & 2.500 & + & $0.74 b c$ & $1.83 \mathrm{bcd}$ \\
\hline G & 90 & 44 & 30 & 2.500 & 11,3 & 44 & 30 & 2.500 & + & $1.18 \mathrm{ab}$ & $2.14 \mathrm{ab}$ \\
\hline
\end{tabular}

Remarks: *: Fertilizer dosage is equivalent to that in the full monoculture population (the population in intercropping consisted of $59 \%$ corn and $61 \%$ soybean).

**: Rhizobium lletrisoy/Agrisoy (seed treatment)

$* * *$ : Include husk + cob + stover (stem and leaves)

****: Means followed by the same letters within the same column are not significantly different based on the LSD test at $5 \%$

height that was not fertilized (control) was 145.8 $\mathrm{cm}$, while the plants treated with the fertilization packages were quite tall, ranging from 166.1 - 176.5 $\mathrm{cm}$. The tallest plants grew in the $\mathrm{D}$ fertilization package, namely $176.5 \mathrm{~cm}$.

The chlorophyll content of leaves at 56 days after planting increased with the treatment of fertilization packages. In the treatment without fertilizer (Package A), the leaf chlorophyll index was 30.13, while in plants fertilized, the leaf chlorophyll index ranged from 38.70 to 41.33 . The application of higher $\mathrm{N}$ fertilizer $(90 \mathrm{~kg} / \mathrm{ha})$ in $\mathrm{E}, \mathrm{F}$, and $\mathrm{G}$ packages did not significantly increase the chlorophyll content compared to $\mathrm{B}, \mathrm{C}$, and $\mathrm{D}$ packages.

\section{Nutrient content in corn plants}

The content of $\mathrm{N}, \mathrm{P}$, and $\mathrm{K}$ nutrients in the leaves below the cobs at 60 days after planting was $1.25-1.84 \%, 0.10-0.14 \%$, and $0.66-0.87 \%$, respectively. All fertilization packages increased the $\mathrm{N}$ content, while the fertilizer packages did not much influence the $\mathrm{P}$ and $\mathrm{K}$ nutrient content due to the relatively low $\mathrm{N}$ content in the soil and the high $\mathrm{P}$ and $\mathrm{K}$ content (Table 2).

Considering the yield of soybean and corn seeds and the biomass as by-products, the best fertiliza- tion package in this study was the $\mathrm{F}$ package. The type and dose of this fertilizer package were $90 \mathrm{~kg}$ $\mathrm{N}+2,500 \mathrm{~kg} / \mathrm{ha}$ manure for corn plants (monoculture equivalent to 33,000 clumps/ha), and 11.3 $\mathrm{kg} \mathrm{N}+36 \mathrm{~kg} \mathrm{P} 2 \mathrm{O} 5+30 \mathrm{~kg} \mathrm{~K} 2 \mathrm{O}+2,500 \mathrm{~kg} / \mathrm{ha}$ manure + Rhizobium Iletrisoy/Agrisoy (seed treatment) for soybean plants (monoculture equivalent with a clump of $166,000 /$ ha). If calculated based on the number of clumps in the intercropping in this study, the fertilizer doses were $53.1 \mathrm{~kg} \mathrm{~N}+$ $1,475 \mathrm{~kg}$ manure per ha for corn plants and 6.9 $\mathrm{kg} \mathrm{N}+22 \mathrm{~kg} \mathrm{P} 2 \mathrm{O} 5+18.3 \mathrm{~kg} \mathrm{~K} 2 \mathrm{O}+1,525 \mathrm{~kg} / \mathrm{ha}$ of manure per ha + Rhizobium Iletrisoy/Agrisoy (seed treatment) for soybean plants.

\section{The yield of corm seeds and biomass as by-products}

The yield of dry corn seeds was generally meager, ranging from only 0.37 to $1.38 \mathrm{t} /$ ha (Table 7) due to the low harvested plant population, which was only $18.80-41.02 \%$ of what should be in the intercropping system (Table 5) due to a downy mildew attack. The highest yield of corn was observed in the E fertilizer package.

The fertilizer packages affected the weight of dry biomass as a by-product, including the husk, cob, and stover (stem and leaves), ranging from 0.88 to 
$2.50 \mathrm{t} / \mathrm{ha}$. The highest yield of biomass was also obtained in the E fertilization package.

\section{CONCLUSION}

On dry land with a dry climate and Vertisol (Grumusol) soil, which was deficient in organic $\mathrm{C}$ and $\mathrm{N}$ nutrients and rich in $\mathrm{P}$ and $\mathrm{K}$ nutrients, the fertilization packages prospectively developed for intercropping double row corn plants $((50 \mathrm{~cm} \mathrm{x}$ $200 \mathrm{~cm}) \times 40 \mathrm{~cm})$ and soybean plants $(40 \mathrm{~cm} \times 15$ $\mathrm{cm}$ ) were $53 \mathrm{~kg} \mathrm{~N}+1,500 \mathrm{~kg}$ manure/ha for corn plants and $7 \mathrm{~kg} \mathrm{~N}+22 \mathrm{~kg} \mathrm{P} 2 \mathrm{O} 5+18 \mathrm{~kg} \mathrm{~K} 2 \mathrm{O}+$ $1,500 \mathrm{~kg} / \mathrm{ha}$ of manure per ha + Rhizobium Iletrisoy/Agrisoy (seed treatment) for soybean plants.
Nitrogen di Lahan Pasir Pantai. Thesis. Universitas Gajah Mada. Yogyakarta.

Saparso. 2008. Ekofisiologi Tanaman Kubis Bawah Naungan dan Pemberian Bahan Pembenah Tanah di Lahan Pasir Pantai. Disertasi-S3 Pasca Sarjana UGM, Yogyakarta. 277 hal.

Saragih, D., H. Hamim dan N. Nurmauli. 2013. Pengaruh Dosis dan Waktu Aplikasi Pupuk Urea dalam Meningkatkan Pertumbuhan dan Hasil Jagung (Zea mays L.) Pioneer 27. J. A grotek Tropika 1(1) : 50-54.

Suwardi dan R. Efendi. 2009. Efisiensi Penggunaan Pupuk N pada Jagung Komposit Menggunakan Bagan Warna Daun. Balai Penelitian Tanaman Serelia. $115 \mathrm{hlm}$.

Taiz L, E. Zeiger. 1991. Plant physiology. Benyamin/ Cumming. Tokyo.

Taufika, R. 2011. Pengujian Beberapa Dosis pupuk Organik Cair Terhadap Pertumbuhan dan Hasil Tanaman Wortel (Daucus carota L.). Jurnal Tanaman Hortikultura.

\section{REFERENCES}

Dwijoseputro, D. 2004. Pengantar Fisiologi Tumbuhan. Gramedia pustaka Utama : Jakarta.

Gardner, F. P., R. B. Pearce dan R. L. Mitchell. 1991. Fisiologi Tanaman Budidaya. Terjemahan, Herawati Susilo. UI Press. Jakarta.

Goldsworrthy, P.R. dan N.M. Fisher. 2000. Fisiologi Tanaman Budidaya Tropik. Penerbit Gadjah Mada University Press. Yogyakarta.

Hanum, C. 2008. Teknik Budidaya Tanaman Jilid 1. Departemen Pendidikan Nasional, Jakarta.

Harjadi, S. 2002. Pengantar Agronomi. Gramedia. Jakarta. 197 hal.

Jumin, H.B. 2002. Agroekologi. Suatu Pendekatan Fisiologi. Rajagrafindo Persada. Jakarta.

Lingga, P. 1998. Petunjuk Penggunaan Pupuk. Penebar Swadaya. Jakarta.

Marvelia, A., S. Darmanti, dan S. Parman. 2006. Produksi Tanaman Jagung Manis (Zea mays L. Saccharata) yang Diperlakukan Dengan kompos Kascing Dengan Dosis yang Berbeda. Buletin Anatomi dan Fisiologi 16(2) : 7-18.

Munawar, A. 2011. Kesuburan Tanah dan Nutrisi Tanaman. IPB Press. Bogor. $240 \mathrm{Hal}$.

Rafli, M., dan Marni, Y. 2010. Pertumbuhan dan Hasil Tanaman Jagung (Zea mays) dengan pemberian pupuk organik BioP2000Z Takaran pupuk anorganik. Jurnal Embrio. (3)(2)(60-67) 2010.

Rajiman, P. Yudono, E. Sulistyaningsih dan E. Hanudin, 2008. Pengaruh Pembenah Tanah Terhadap Sifat Fisika Dan Hasil Bawang Merah Pada Lahan Pasir Pantai Bugel. Jurnal Agin 12 (1): 67-77.

Ramadhani, R.H, M. Roviq dan M.D. Maghfoer. 2016. Pengaruh Sumber Pupuk Nitrogen dan Waktu Pemberian Urea pada Pertumbuhan dan Hasil Jagung Manis. Jurnal Produksi Tanaman $4(1): 8-15$.

Rosmarkam, A dan N.W. Yuwono. 2002. Ilmu Kesuburan Tanah. Kanisius. Yogyakarta. 59 hal.

Saparso. 2001. Kajian Serapan Nitrogen dan Pertumbuhan Tanaman Kubis pada Berbagai Kombinasi Mulsa dan Dosis Pupuk 